\title{
Chemical Dissolution of Cellulose Membranes as a Prerequisite for Penetration from Appressoria of Colletotrichum lagenarium
}

\author{
By K. SUZUKI, * I. FURUSAWA, N. ISHIDA AND M. YAMAMOTO \\ Laboratory of Plant Pathology, Faculty of Agriculture, Kyoto University, Kyoto 606, Japan
}

(Received 28 April 1981; revised 14 September 1981)

The relationship between protein synthesis during appressorial formation and the ability of appressoria to form penetration hyphae in nitrocellulose membranes was investigated for the plant pathogenic fungus Colletotrichum lagenarium. Cycloheximide treatment before appressorial pigmentation inhibited the formation both of penetration hyphae and of haloes, the latter resulting from the partial degradation of cellulose membranes; but treatment after appressorial pigmentation did not inhibit halo formation. When spores were transferred to $32{ }^{\circ} \mathrm{C}$ before appressoria became pigmented, both pigmentation and penetration were prevented. In the presence of $1 \mathrm{~mm}$-3,4-dihydroxyphenylalanine (DOPA) at $32{ }^{\circ} \mathrm{C}$, pigmentation was restored, but the formation of haloes and penetration hyphae was still prevented. Penetration into cellulose membranes pretreated with cellulase was observed from $20-30 \%$ of appressoria which had been formed in the presence of cycloheximide at $24{ }^{\circ} \mathrm{C}$ or in the presence of DOPA at $32{ }^{\circ} \mathrm{C}$. The results suggest that there are two phases of protein synthesis following spore germination, only the first of which is involved in halo formation.

\section{INTRODUCTION}

In some plant pathogenic fungi, formation of appressoria is a prerequisite for invasion of host plants (Emmett \& Parbery, 1975). A relationship between appressorial formation and protein and RNA synthesis has been reported for a few plant pathogens (Dunkle et al., 1969; Miehle \& Lukezic, 1972; Staples \& Yaniv, 1976), but whether protein synthesis is involved in the process of penetration from appressoria has not been established.

Formation of appressoria in Colletotrichum lagenarium is temperature sensitive: appressoria form when spores are incubated at $24{ }^{\circ} \mathrm{C}$, but do not form at $32{ }^{\circ} \mathrm{C}$ (Ishida \& Akai, 1969). A polypeptide with a molecular mass of 95 kilodaltons was specifically associated with appressorial formation, and when its synthesis was inhibited by cycloheximide, appressoria matured in structure, but seemed to lack the ability to penetrate artificial nitrocellulose membranes (Suzuki et al., 1981).

This paper reports the effects of temperature and cycloheximide on the formation of penetration hyphae and of haloes resulting from the partial degradation of the nitrocellulose membrane. The significance of protein(s) synthesized during appressorial formation on the ability to form penetration hyphae in membranes is discussed.

\section{METHODS}

Spores. Colletotrichum lagenarium (Pass.) Ellis and Halsted was cultured on potato sucrose agar medium at $24{ }^{\circ} \mathrm{C}$ for $7 \mathrm{~d}$. Spores on the mycelial mat were collected with a brush and washed three times by centrifugation with ice-cold distilled water (Furusawa et al., 1977).

Spore germination. The spores were suspended in deionized sterile water at about $1 \times 10^{5}$ spores $\mathrm{ml}^{-1}$. Drops of the spore suspension were placed on glass slides in humid Petri dishes at various temperatures.

Observations on the penetration of nitrocellulose membranes. A nitrocellulose membrane $(2 \times 2 \mathrm{~cm})$, prepared from Visking cellulose tubing, was coated with a uniform suspension of spores and soaked in $2 \mathrm{ml}$ sterile distilled water in a Petri dish $(4.5 \mathrm{~cm}$ diam.). After various incubation times, the water was exchanged for $2 \mathrm{ml}$ of a solution of $3.55 \mu \mathrm{M}$-cycloheximide or $1 \mathrm{mM}$-3,4-dihydroxyphenylalanine (DOPA). Removal of cycloheximide was done as described previously (Suzuki et al., 1981). After incubation the membranes were stained with lactophenol cotton blue or $\mathrm{ZnCl}_{2} / \mathrm{KI}$ solution.

Partially denatured nitrocellulose membranes were prepared by treatment with $2 \%(\mathrm{w} / \mathrm{v})$ cellulase (Onozuka $\mathrm{R}-10$, Kinki Yakult, Japan) for $6 \mathrm{~h}$ at $30^{\circ} \mathrm{C}$. 
Table 1. Effect of $3.55 \mu \mathrm{M}$-cycloheximide on formation of penetration hyphae and haloes by C. lagenarium on nitrocellulose membranes

Spores were incubated at $16^{\circ} \mathrm{C}$ on nitrocellulose membranes. At the indicated time, spores were transferred to $24^{\circ} \mathrm{C}$, cycloheximide was added and incubation continued until $60 \mathrm{~h}$.

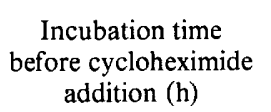

6

12

18

24

30

36
Percentage of spores with pigmented appressoria when cycloheximide added

0
$12 \cdot 8$
$50 \cdot 3$
$75 \cdot 0$
$81 \cdot 5$
$86 \cdot 8$

\section{Percentage of appressoria with:}

$\overbrace{\text { Penetration hyphae* } \text { Haloes }^{*}}$

\footnotetext{
* The numbers in parenthesis are the percentages of appressoria with penetration hyphae or haloes at the time of addition of cycloheximide.
}

Table 2. Effect of $3.55 \mu \mathrm{M}$-cycloheximide treatment before and after appressorial pigmentation on formation of penetration hyphae and haloes by $C$. lagenarium on nitrocellulose membranes

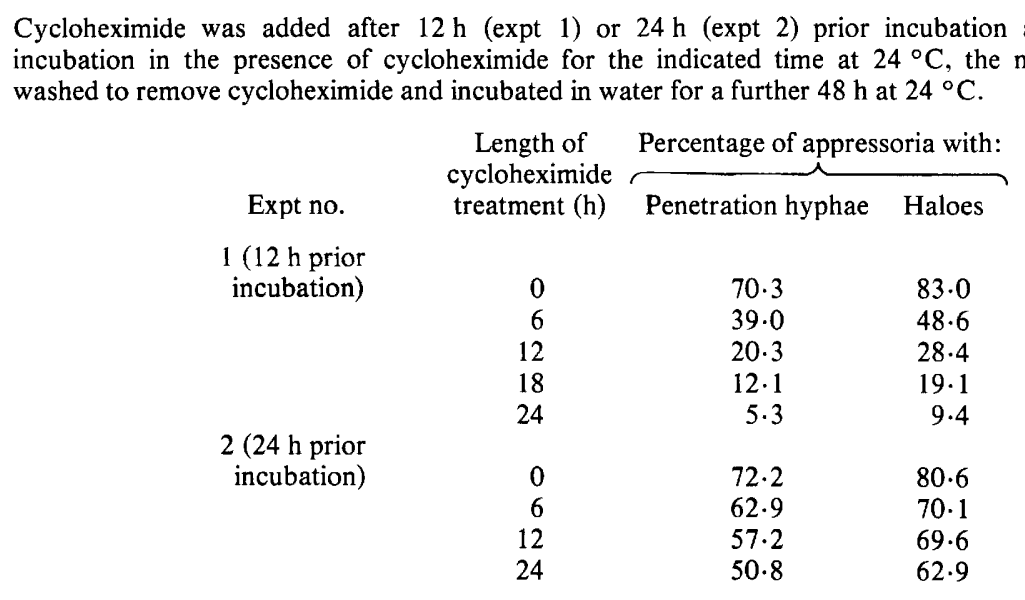

\section{RESULTS}

When spores were incubated on nitrocellulose membranes at $16^{\circ} \mathrm{C}$, there was little overlap between the phases of appressorial formation, pigmentation and penetration, all of which were delayed relative to $24^{\circ} \mathrm{C}$. By $12 \mathrm{~h}$ appressoria had attained full size, but were unpigmented, while by $24 \mathrm{~h}$ they were structurally mature and dark pigmented. After $24 \mathrm{~h}$ at $16^{\circ} \mathrm{C}$, transfer of spores to $24^{\circ} \mathrm{C}$ permitted the synchronous formation of penetration hyphae which were accompanied by the formation of haloes indicating partial digestion of the membranes.

After various incubation times at $16^{\circ} \mathrm{C}$, cycloheximide $(3.55 \mu \mathrm{M})$ was added to spore suspensions. Formation of penetration hyphae was almost completely inhibited irrespective of the time of cycloheximide addition (Table 1). Halo formation was inhibited by addition of cycloheximide within $12 \mathrm{~h}$ of incubation, whereas it was not affected by addition of cycloheximide at and after $24 \mathrm{~h}$ regardless of complete inhibition of formation of penetration hyphae (Table 1). When cycloheximide was added before appressoria had matured in structure and pigmentation $\left(12 \mathrm{~h}\right.$ at $\left.16^{\circ} \mathrm{C}\right)$ and removed after they had so matured, haloes and penetration hyphae were rarely observed even after a further $48 \mathrm{~h}$ incubation (Table 2 , Expt 1). However, if cycloheximide was added after appressoria had coloured $\left(24 \mathrm{~h}\right.$ at $\left.16^{\circ} \mathrm{C}\right)$ 
Table 3. Effects of temperature on appressorial pigmentation, lateral germination from appressoria and penetration by C. lagenarium, following $12 \mathrm{~h}$ preincubation at $16^{\circ} \mathrm{C}$

\begin{tabular}{|c|c|c|c|c|}
\hline \multirow{2}{*}{$\begin{array}{c}\text { Temperature } \\
\left({ }^{\circ} \mathrm{C}\right)\end{array}$} & \multirow{2}{*}{$\begin{array}{l}\text { Percentage of } \\
\text { pigmented } \\
\text { appressoria* }\end{array}$} & \multirow{2}{*}{$\begin{array}{l}\text { Percentage of } \\
\text { lateral germination } \\
\text { from appressoria* }\end{array}$} & \multicolumn{2}{|c|}{ Percentage of appressoria with: } \\
\hline & & & Penetration hyphae ${ }^{\dagger}$ & Haloest \\
\hline 16 & $94 \cdot 3$ & $2 \cdot 4$ & $61 \cdot 1$ & $66 \cdot 0$ \\
\hline 20 & $96 \cdot 7$ & $2 \cdot 1$ & $72 \cdot 3$ & $73 \cdot 4$ \\
\hline 24 & $95 \cdot 7$ & $2 \cdot 4$ & $75 \cdot 0$ & $83 \cdot 5$ \\
\hline 28 & $72 \cdot 7$ & $14 \cdot 3$ & $51 \cdot 0$ & $66 \cdot 2$ \\
\hline 32 & $16 \cdot 3$ & $31 \cdot 0$ & $3 \cdot 7$ & $12 \cdot 4$ \\
\hline
\end{tabular}

\footnotetext{
* Spores were incubated at $16^{\circ} \mathrm{C}$ for $12 \mathrm{~h}$, transferred to the temperatures shown and incubated for a further $24 \mathrm{~h}$ on glass slides.

$\dagger$ Spores were incubated at $16^{\circ} \mathrm{C}$ on nitrocellulose membranes for $12 \mathrm{~h}$, transferred to the temperatures shown and incubated for a further $48 \mathrm{~h}$.
}

Table 4. Effects of temperature and DOPA on appressorial pigmentation and the formation of penetration hyphae and haloes by $C$. lagenarium on nitrocellulose membranes following $12 \mathrm{~h}$ preincubation at $16^{\circ} \mathrm{C}$

Spores were incubated on nitrocellulose membranes at $16^{\circ} \mathrm{C}$ for $12 \mathrm{~h}$, followed by incubation for a further $48 \mathrm{~h}$ at 24 or $32{ }^{\circ} \mathrm{C}$ in the presence $(+)$ or absence $(-)$ of $1 \mathrm{~mm}$-DOPA.

$\begin{array}{ccccc}\begin{array}{c}\text { Temperature }\left({ }^{\circ} \mathrm{C}\right) \\ \text { to which spores } \\ \text { transferred after } 12 \mathrm{~h}\end{array} & \begin{array}{c}\text { Presence } \\ \text { of DOPA }\end{array} & \begin{array}{c}\text { Pigmented } \\ \text { appressoria }\end{array} & \begin{array}{c}\text { Penetration } \\ \text { hyphae }\end{array} & \text { Haloes } \\ 24 & - & 94.8 & 79.8 & 83.2 \\ 32 & + & 97.6 & 72.4 & 76.6 \\ & - & 12.9 & 4 \cdot 1 & 14.0 \\ & + & 92.9 & 0 & 3.8\end{array}$

Table 5. Effect of temperature on the formation of penetration hyphae and haloes by C. lagenarium on nitrocellulose membranes following $24 \mathrm{~h}$ preincubation at $16^{\circ} \mathrm{C}$

Spores were incubated at $16^{\circ} \mathrm{C}$ for $24 \mathrm{~h}$ on nitrocellulose membranes then transferred to the temperatures shown and incubated for a further $36 \mathrm{~h}$.

$\begin{array}{ccc}\text { Temperature } & \overbrace{\text { Penetration hyphae }} & \text { Haloes } \\ 16 & 61 \cdot 1 & 66 \cdot 0 \\ 20 & 72 \cdot 2 & 72 \cdot 3 \\ 24 & 71 \cdot 4 & 73 \cdot 0 \\ 28 & 67 \cdot 7 & 74.9 \\ 32 & 66 \cdot 2 & 73 \cdot 1\end{array}$

and removed after a further $24 \mathrm{~h}$ incubation, both haloes and penetration hyphae were observed (Table 2, Expt 2). These results suggest that protein synthesis involved in halo formation occurs during maturation of appressoria.

When spores were incubated at $16^{\circ} \mathrm{C}$ for $12 \mathrm{~h}$ and transferred to a temperature within the range 16 to $32{ }^{\circ} \mathrm{C}$ before appressoria had coloured, percentage formation of haloes and penetration hyphae decreased at $32{ }^{\circ} \mathrm{C}$ (Table 3 ). In addition, the percentage of appressorial pigmentation decreased at $32{ }^{\circ} \mathrm{C}$ and about $30 \%$ of appressoria developed germ tubes laterally from appressoria when incubated on glass slides (Table 3 ).

In order to clarify the relationship between appressorial pigmentation and the ability to penetrate cellulose membranes, appressorial pigmentation was induced at $32{ }^{\circ} \mathrm{C}$ by the addition of DOPA (1 mM), a known melanin precursor (Bull, 1970). Pigmented appressoria 
did not germinate laterally but neither penetration hyphae nor haloes were regularly observed (Table 4), suggesting that protein synthesis involved in halo formation might be temperature sensitive and not occur at $32^{\circ} \mathrm{C}$. The percentage of halo formation was dependent on the timing of the temperature shift from 16 to $32^{\circ} \mathrm{C}$. Treatment with DOPA at $24^{\circ} \mathrm{C}$ did not affect the formation of penetration hyphae and haloes (Table 4). On the other hand, if spores were incubated at $16^{\circ} \mathrm{C}$ for $24 \mathrm{~h}$ (appressoria mature in structure and pigmentation) and transferred to a temperature within the range 16 to $32^{\circ} \mathrm{C}$, the formation of haloes and penetration hyphae was not affected. Therefore, following a $24 \mathrm{~h}$ preliminary incubation the formation of haloes and penetration hyphae was not temperature-dependent (Table 5).

To determine whether halo formation is essential for penetration or not, spores were incubated on nitrocellulose membranes which had been treated previously with $2 \%(\mathrm{w} / \mathrm{v})$ cellulase for $6 \mathrm{~h}$ at $30{ }^{\circ} \mathrm{C}$. From $20-30 \%$ of appressoria which were formed in the presence of cycloheximide $(3.55 \mu \mathrm{M})$ at $24^{\circ} \mathrm{C}$ or those coloured in the presence of DOPA $(1 \mathrm{mM})$ at $32^{\circ} \mathrm{C}$, penetration into cellulose membranes previously treated with cellulase occurred, whereas penetration was rarely observed into membranes which were not treated with cellulase.

\section{DISCUSSION}

The formation of appressoria is necessary for infection by many plant pathogenic fungi (Emmett \& Parbery, 1975). To date, studies have been concerned mainly with the relationship between macromolecular synthesis and appressorial morphogenesis (Dunkle et al., 1969; Miehle \& Lukezic, 1972; Staples \& Yaniv, 1976), and there is little information available on the involvement of protein synthesis in host penetration by appressoria.

Our results suggest that the requirement for protein synthesis during penetration from appressoria can be divided into two phases. One phase occurs during appressorial maturation and may be closely connected with halo formation. The other occurs after the structural maturation of appressoria and seems to be required for the elongation of penetration hyphae, because treatment with cycloheximide after appressorial maturation with pigmentation inhibited the appearance of penetration hyphae but not of haloes. Appressoria which lack the ability to penetrate - those formed in the presence of cycloheximide (Suzuki et al., 1981) or those coloured in the presence of DOPA at $32{ }^{\circ} \mathrm{C}$ - successfully penetrated membranes previously treated with cellulase. This suggests that the formation of haloes is caused by the partial digestion of cellulose and is probably essential for the development of penetration hyphae. Appressorial formation and pigmentation were temperature sensitive and did not occur at $32{ }^{\circ} \mathrm{C}$. Results in this study suggest that appressorial pigmentation was not directly connected with the synthesis of proteins necessary for halo formation, because at $32^{\circ} \mathrm{C}$ penetration hyphae were not observed even if appressorial pigmentation was induced by DOPA.

We have already reported that a polypeptide with a molecular mass of 95 kilodaltons was specifically synthesized only when appressoria were formed (Suzuki et al., 1981). As shown in Tables 3 and 4 , the early phase of protein synthesis necessary for halo formation might be temperature sensitive and be inhibited at $32^{\circ} \mathrm{C}$. It is probable that the 95 kilodalton polypeptide (Suzuki et al., 1981) might be cellulase itself or another related molecule which results in halo zones around the penetration sites.

\section{REFERENCES}

BúLL, A. T. (1970). Chemical composition of wild-type and mutant Aspergillus nidulans cell walls. The nature of polysaccharide and melanin constituents. Journal of General Microbiology 63, 75-94.

Dunkle, L. D., Maheshwari, R. \& Allen, P. J. (1969). Infection structures from rust uredospores: effect of RNA and protein synthesis inhibitors. Science 163, 481-482.

EMmetT, R. W. \& PARbery, D. G. (1975). Appressoria. Annual Review of Phytopathology 13, 147-167.

Furusawa, I., Nishiguchi, M., Tani, M. \& Ishida, 
N. (1977). Evidence of early protein synthesis essential to the spore germination of Colletotrichum lagenarium. Journal of General Microbiology 101, 307-310.

IsHIDA, N. \& AKAI, S. (1969). Relation of temperature to germination of conidia and appressorium formation in Colletotrichum lagenarium. Mycologia 61, 382-386.

Miehle, B. R. \& Lukezic, F. L. (1972). Studies on conidial germination and appressorium formation by Colletotrichum trifolii Bain \& Essary. Canadian Journal of Microbiology 18, 1263-1269.
Staples, R. C. \& Yaniv, Z. (1976). Protein and nucleic acid metabolism during germination. In Encyclopedia of Plant Physiology New Series 4, Physiological Plant Pathology, pp. 86-103. Edited by R. Heitefuss \& P. H. Williams. Berlin: SpringerVerlag.

Suzuki, K., Furusawa, I., Ishida, N. \& Yamamoto, M. (1981). Protein synthesis during germination and appressorium formation of Colletotrichum lagenarium spores. Journal of General Microbiology 124, 61-69. 